\title{
The roots of modern British cardiology
}

\author{
DENNIS M KRIKLER
}

\section{From the Cardiovascular Division, Royal Postgraduate Medical School, London}

The nineteenth century abounds with the names of individual British physicians expert in cardiac disease who wrote of its pathology, diagnosis, and management. As a group, however, they were not cardiologists as we would understand the term today; nor could they have been, when the new techniques available at the start of that century-percussion and auscultation-were just being added to the conventional methods-taking the history, inspection, and palpation. British interest in auscultation was immediate. Sir James Clark, who later attended John Keats the poet, acquired a stethoscope in Paris in $1818^{1}$ and introduced Sir John Forbes to its use. Forbes translated (and modified) Laennec's book. ${ }^{2}$ While he was still a student, William Stokes of Dublin wrote the first British book on the use of the stethoscope. ${ }^{3}$ By 1819 , stethoscopes were on sale in London, ${ }^{1}$ being mainly used in diseases of the chest. And yet, as the century ended, cardiology was taking on the forms of a subspecialty of general medicine, not yet crystallised but in retrospect already evident. These physicians would not have labelled themselves as heart specialists, and often combined their interest in the heart with an interest in respiratory medicine and indeed even wider activities. Most of the consultant members on the staff of the original National Hospital for the Diseases of the Heart held appointments elsewhere that covered many other aspects of medicine. ${ }^{4}$

What then might have determined how cardiology developed? This can only be assessed in retrospect by identifying landmarks now known to have been important in leading to new methods of diagnosis and treatment. Similar events occurred in parallel in other European countries as well as the United States.

It is important to put matters into the perspective of the times. The events just mentioned occurred less

Based on the George Burch Memorial Lecture given to the Association of University Cardiologists, Carmel, California, on 19 January 1989.

Requests for reprints to Dr Dennis M Krikler, Royal Postgraduate Medical School, 150 Ducane Road, London W12 0NN. than two centuries after Harvey's discovery of the circulation and less than half a century after two os seminal advances-the introduction of digitalis by $\omega$ Withering ${ }^{5}$ and the appreciation of the nature of $\mathrm{N}_{\mathrm{w}}^{\mathrm{N}}$ angina pectoris through the observations of Heberden, ${ }^{6}$ Jenner, ${ }^{7}$ and Parry. ${ }^{8}$ They coincided with the $\frac{}{I}$ appearance of some of the classic texts on heart $\vec{c}$ disease by leading British (and Irish) physicians of $\mathbb{D}$ the first part of the nineteenth century, which reflected the clinical advances to that time: Burns, though primarily an anatomist, proposed the $\Phi$ ischaemic theory of angina pectoris $;$; and Adams, ${ }^{10} \overrightarrow{.}$ Hope, ${ }^{11}$ Latham, ${ }^{12}$ and Stokes ${ }^{13}$ were the key authors of the textbooks of the day. These took account of the clinical developments to that time, but gradually, based on the new physiology that developed in France under Claude Bernard and Germany under Carl Ludwig, techniques were introduced that were to alter the study of heart disease and bring us to the cardiology - and cardiologist - of today. Participants in this process included the famous and the unrecognised, those actively and consciously engaged, and those whose contribution can only be acknowledged long afterwards. And even then, this can only be a $\vec{\nabla}$ selective account of some of the physicians and events concerned in the establishment of modern British cardiology. Lawrence has surveyed this period in some detail, with interesting philosophical insights. He focuses on changing attitudes at the basic as well as the clinical level, ${ }^{14}$ and looks critically at developments from the perspective of the non-cardiologist.

\section{Pulse recordings}

Just when examination of the cardiovascular system $N$ was being improved by the greater use of devices to $N$ enhance the senses of touch and hearing, to assess structure, it became clear that there was also the needo for the physician to assess the function of the $\overparen{D}$ circulation more appropriately. Not even Harvey had $\stackrel{\mathcal{P}}{+}$ applied his concepts to the care of man, so it was timely that during the first half of the nineteenth century several physiologists tried to fill this gap and $\stackrel{\mathbb{P}}{\mathscr{P}}$ developed techniques for recording the pulse directly $\stackrel{\mathbb{Q}}{\Omega}$ from the arteries and veins of living animals. Among 
the foremost of these physiologists was Carl Ludwig of Leipzig, who taught the teachers-many of whom became pioneers of modern physiology. Closer to the clinical level was Etienne-Jules Marey of Paris, who made clinical recordings of the pulse from the surface of the intact body of a patient as early as 1857; his doctoral thesis of 1859 was cited by others even before he published his definitive study in $1863 .{ }^{15} \mathrm{By}$ 1870 , Lorain was able to produce a substantial text on disorders of the pulse, comprising 372 pages and containing 488 figures. Most of the figures were pulse tracings made on drums of smoked paper.$^{16} \mathrm{He}$ reviewed eleven major studies that had appeared in the preceding decade, several of them British (some individual parts of serial publications may have been cited separately yet others were missed). According to Foster, of Birmingham, the Marey sphygmograph was first demonstrated in Britain by Dr Hughes Bennett in Bath in $1864^{17}$ : claims for priority led to acrimonious correspondence. John Burdon-Sanderson (soon to become professor of physiology at University College, London, and later Oxford) and Anstie wrote a series of major articles on pulse recordings, starting in $1866 .{ }^{18}$ But a key figure in medical practice, Sir Lauder Brunton-then a medical student-had also started to use pulse tracings, and was soon to make other important contributions to cardiological practice.

When Thomas Lauder Brunton (1844-1916) ${ }^{19}$ qualified from Edinburgh in 1866 he was preparing an $M D$ thesis on digitalis that was published in 1868 and reprinted in his collected works. ${ }^{20}$ In the preface to this collection he recalled that when he started his studies on digitalis there were only one or two of Marey's sphygmographs available in the United Kingdom. Burdon-Sanderson had not yet made one, but Brunton was able to borrow one from Arthur Gamgee (now remembered, if at all, for his layered bandage) who supervised his studies. Although these studies were performed barely 80 years after Withering's publication, digitalis had already fallen into neglect as a remedy for heart disease. ${ }^{21}$ While Brunton continued to study the pulse-his subsequent work was cited by Mackenzie-at virtually the same time, and on the basis of what he gleaned from Gamgee, he discovered the value of the vasodilator amyl nitrite in angina pectoris. ${ }^{22}$ This was soon to be supplanted by glyceryl trinitrate, which was introduced by Murrell of the Westminster Hospital, ${ }^{23}$ but Brunton and his contributions should not be forgotten. He should also be remembered as one of the pioneer physiologists. On an extensive continental postgraduate tour in $1867-8$ he included a visit to Ludsvig in Leipzig, and in 1876 when Burdon-Sanderson invited the leading physiologists of the day to a meeting at his home to establish the Physiological
Society, Brunton was one of those present. ${ }^{24}$ Lawrence $^{14}$ stresses the importance of some of Brunton's other contributions, including his suggestion that mitral stenosis would prove amenable to surgical treatment; he clearly played an important role in the development of cardiology. The close links between physiology and clinical practice at that time are further attested by Burdon-Sanderson's career. He was successively Jodrell professor of physiology at University College, London, and Waynflete professor of physiology at Oxford before becoming regius professor of medicine there. He was Harveian orator of the Royal College of Physicians, which also awarded him its Bayly medal.

\section{The Mackenzie era}

Although Sir James Mackenzie was the key figure in shaping British cardiology, he was by inclination a general practitioner, and he worked as one for most of his professional life, despite being considered as the most famous cardiologist in the world by the European physicians visited by Arthur Hurst in 1906": "Of all English physicians, the best known and most frequently quoted in Germany is probably Dr Mackenzie of Burnley, a prophet who has hardly met in his own country with the recognition which he deserves." Soon after Mackenzie started practice in Burnley in Lancashire his interest in cardiology was stimulated by unexplained tragedies among his patients, including puerperal death from heart disease.$^{26} \mathrm{He}$ also observed unexplained irregularities in the rhythm of the heart and recognised that "if graphic records of the venous pulse, with a standard time, could be obtained, much light might be thrown upon the subject." ${ }^{26}$ Initially unaware of the work of Marey and others, he tried to develop an instrument himelf, but "when at last I did succeed . . . both the method and the results had been already described." ${ }^{26}$ In the first place, he applied a funnel over a pulsating vessel and connected it to a tambour and lever that inscribed the tracing on the smoked paper of a cylinder, adapting the sphygmograph introduced by Dudgeon ${ }^{27}$ to this purpose. By 1892 he was working with an apparatus that could record several pulses simultaneously, from vein, artery, or the cardiac apex, made for him by Krohne and Sesemann in London, ${ }^{26}$ though he did appreciate the fact that Potain had already obtained simultaneous venous and carotid tracings in 1868 and he knew that Brunton had still been working on pulse recordings in 1879. Mackenzie's monograph on the pulse in $1902^{28}$ was extended by a series of papers in the British Medical Journal three years later, which made his work even more widely known, ${ }^{29}$ but the usefulness of his techniques was greatly enhanced by the 
ink polygraph that he developed with Sebastian Shaw, a watchmaker in Padiham, Lancashire, in $1906 .^{30}$ Mackenzie had attributed the arrhythmia that we now recognise as atrial fibrillation to inception of the rhythm in the ventricle, later considering that it arose in the atrioventricular node; but once its true nature was established, he accepted it, though not without some reservations. ${ }^{31}$ In 1907 he moved to London, where he was soon to encourage Lewis to undertake his electrocardiographic studies, but we should not forget that when he was a general practitioner in Burnley "distinguished men like Osler, Keith, Wenckebach, physicians, anatomists, physiologists, and others, were finding their way to Bank Parade, impressed by the importance of Mackenzie's work, and desirous of meeting the man himself. His reputation reached far, and his opinion was sought by medical men and their patients, not only from Great Britain, but also from Canada, America, Germany, and France." 25

Mackenzie's move, at the age of 54, was not easy, and it was another five years before he was appointed to the staff of the London Hospital, though his success in private practice was immediate and great. ${ }^{25}$ In Lewis he found a young colleague whose initial researches and editorial ventures he could stimulate. Together, during the first world war, they studied the effort syndrome. Unfortunately, his years in London and St Andrews were dogged by vascular disease $^{32}$; indeed he had been troubled by arrhythmias-self diagnosed with his polygraph-almost from the day he devised the instrument. As early as 1893 , at the age of 40 , he had experienced and recorded extrasystoles. In 1901 he suffered his first attack of atrial fibrillation, which he confirmed with the polygraph; it lasted two hours. At the age of 53 he developed angina pectoris and the next year had a myocardial infarct. Subsequently he had more severe angina and recurrent episodes of atrial fibrillation and his last years were clouded by worsening vascular disease.

Mackenzie had many distinguished disciples: Lewis was too independent to fall into this category. Two are now singled out, though many members of the Cardiac Club as well as others could fall into this category. John Hay of Liverpool $(1873-1959)^{33}$ fell under Mackenzie's spell and through him met Wenckebach when he came over to visit; Hay later spent some time in Groningen before being given special responsibility for cardiac patients in Liverpool. Not surprisingly, Hay's contributions included the study of atrioventricular conduction. Another, better known, pupil, Sir John Parkinson, contributed in many ways, not the least being the systematic analysis that he carried out with Evan Bedford of the role of the electrocardiograph in the diagnosis of cardiac infarction. ${ }^{34}$ Nowadays he is probably most often recalled as one of the co-authors of the famous paper $\stackrel{.}{\stackrel{5}{4}}$ on pre-excitation. ${ }^{35}$

\section{Sir Thomas Lewis}

Lewis's key role in modern British cardiology, and the importance attached to his work by Einthoven, $\stackrel{\mathbb{Q}}{\triangle}$ have been amply documented..$^{36-38}$ Lewis (1881- in 1945) systematically analysed arrhythmias with the $\vec{O}$ electrocardiograph, established the Journal Heart (which he edited until 1944, its name having been $\vec{\omega}$ changed to Clinical Science in 1933), investigated the of effort syndrome, and was the first chairman of the Cardiac Club when it was established in 1922. His interests shifted into other aspects of clinical inves- $\omega$ tigation once he had published the third edition of his $i$ Mechanism and Graphic Registration of the Heart

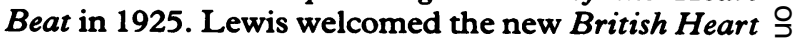
Journal when it first appeared fifty years ago, ${ }^{39}$ thirty $\vec{C}$ years after he had started his own journal. Yet despite $\underset{\Phi}{\mathcal{D}}$ his expertise in electrocardiography, early personal $\frac{\mathbb{O}}{\mathbb{D}}$ studies of the effects of coronary artery ligation in dogs, and awareness of the studies by James $B$ 옹 Herrick and Fred $M$ Smith on the electrocardiographic changes produced clinically and experimentally by coronary artery occlusion, Lewis never used the electrocardiograph to diagnose coronary artery disease. ${ }^{40}$ This could not have been expected of Mackenzie, whose personal studies were confined to the polygraph and who practised before the electrocardiograph was used to elucidate coronary artery disease; Howell suggests that Lewis's analytical processes were based on the polygraph, too. ${ }^{40}$ Both men suffered from chronic coronary artery disease and died of myocardial infarction. Although Parkinson, who became Mackenzie's physician $^{32}$ was actively investigating the use of the electrocardiograph in cardiac infarction, there is no evidence that Mackenzie underwent electrocardiography; in 1927, when Lewis suffered his first cardiac infarct, the diagnosis was confirmed with tracings (A Hollman, personal communication). Though both men were intense and dedicated to their work, they were also able to relax-Mackenzie at golf and Lewis at photography and bird watching, hobbies that he shared with Frank Wilson, the American who fortunately was ready to take up the challenge just as Lewis was withdrawing from electrocardiography.

A look at Lewis's publications shows the many collaborators with whom he worked over the years, and hints at the international influence that he wielded. But one example of an early association, with a physician who played no major role in cardiology, has links with contemporary practice that were impossible to envisage then. Alfred Goodman Levy (1866-1954) became consultant physician to 
the City of London Hospital for Diseases of the Chest in 1912. Although in later life he was a very staid individual, he had spent four very adventurous years in Matabeleland soon after completing his medical studies. ${ }^{41}$ When he returned to London he obtained higher qualifications and then investigated one of the pressing problems of the time-death from chloroform anaesthesia. Ventricular arrhythmias with chloroform had already attracted the interest of John MacWilliam, the Aberdeen physiologist, who had studied ventricular fibrillation since 1887 , and who was a steadfast friend to Mackenzie. ${ }^{42}$ Levy had already shown that arrhythmias occurred during light rather than heavy anaesthesia with chloroform. Fresh studies, made with Lewis, using the electrocardiograph, showed that anaesthesia with low tensions of chloroform when combined with small amounts of intravenous adrenaline caused ventricular fibrillation..$^{43}$ This was half a century before Sir James Black introduced $\beta$ adrenergic blockers, ${ }^{44}$ which have specific antiarrhythmic properties.

Long after he had given up electrocardiography, Lewis remained a major figure in cardiology, writing Diseases of the Heart in 1933. His best known international disciples had worked with him in the two decades encompassing the first world war, but he attracted visitors long afterwards. George Burch, who was to be so important in American cardiology, had arranged to spend two years with him from September 1939 but this was thwarted by the outbreak of the second world war just as he was about to leave New Orleans for London (unpublished letter to H B Burchell). Burch subsequently paid several visits to Britain and attended meetings of the British Cardiac Society. Some of the features of the Association of University Cardiologists, of which he was a founder, reflect his British experience; but the constitution of the association was actually based on that of the Association of University Radiologists in the United States (N P DePasquale, personal communication).

\section{Where next?}

It would be tempting to bring the story up to date, but that would be at the expense of the opportunity for historical reflection. That neither Mackenzie nor Lewis considered themselves cardiologists as we use the term is clear. Mackenzie not only emphasised the importance of general practice but left London to establish the Institute for Clinical Research in St Andrews that was intended to study disease in the community. Lewis changed interests and investigated pain perception and vascular reactions. But they were the cardiologists of their day and recognised as such then and now. Their immediate associates and successors declared an exclusive interest in cardiology in private practice; but in hospital work, in London and the provinces, they were usually general physicians with an interest in cardiology, perhaps with responsibility for its key investigative tool, electrocardiography. This certainly applied to most, though not all, of the original members of the Cardiac Club, established in 1922 and consisting of 15 physicians who were consultants to the Ministry of Pensions on cardiac disability in former soldiers. ${ }^{45}$ Howell points out that the members of the Club wrote little on cardiology, and contributed little by way of research. ${ }^{46}$ This should not surprise us because they were established consultants, all but three were over 40 , and many of them had already written papers, often on arrhythmias analysed with the polygraph and electrocardiograph. Though they may have written little on cardiological matters subsequently, they laid the foundation for their successors to do so, by creating the British Cardiac Society in $1937^{47}$ and the British Heart Journal two years later. As I have already remarked, ${ }^{48}$ over half (12) of the 23 original articles published in the first volume of the British Heart Journal involved the electrocardiograph. Thus the technological advances that produced electrocardiography were indeed crucial to the development of the specialty. As Lawrence points out, "Cardiology as an institutionalized medical speciality did not exist in Britain until after the Second World War."14 It was during that war that cardiac catheterisation was introduced in the United States by Cournand and soon used in Britain. ${ }^{49}$ Cardiac catheterisation helped delineate the specialty of cardiology more clearly, but, as with electrocardiography, an important immediate effect was to clarify symptoms and physical signs ${ }^{50}$; and it did, of course, put the development of cardiac surgery on a secure basis. It will not be long before the impact of such interventions, and of some of their practitioners and exponents, can be assessed-but that time is yet to come.

\section{References}

1 Sakula A. Laennec's influence on some British physicians in the nineteenth century. $J R$ Soc Med 1981;74:759-67.

2 Laennec RTH. A treatise on the diseases of the chest, in which they are described according to their anatomical characters, and their diagnosis established by a new principle by means of acoustick instruments. Translated from the French of RTH Laennec, MD with a preface and notes by John Forbes MD. London: $T$ and $G$ Underwood, 1821.

3 Stokes W. An introduction to the use of the stethoscope. Edinburgh: Maclachlan and Stewart, 1825.

4 Campbell M. The National Heart Hospital 1857-1957. Br Heart J 1958;20:137-9.

5 Withering W. An account of the foxglove, and some of its medical uses: with practical remarks on dropsy, and other diseases. London: G G J and J Robinson, 1785.

6 Heberden W. Some account of a disorder of the breast. Medical transactions, published by the College of 
Physicians in London 1772;2:59-67.

7 Baron J. The life of Edward Jenner, M.D.; with illustrations of his doctrines and selections from his correspondence. London: Henry Colburn, 1827.

8 Parry CH. An inquiry into the symptoms and causes of the syncope anginosa, commonly called angina pectoris. London: Cadell and Davies, 1799.

9 Burns A. Observations on some of the most frequent and important diseases of the heart; on aneurism of the thoracic aorta; on preternatural pulsation in the epigastric region: and on the unusual origin and distribution of some of the large arteries of the human body. Edinburgh: Thomas Bryce and Co, 1809.

10 Adams R. Cases of diseases of the heart accompanied with pathological observations. Dublin: Hodges and M'Arthur, 1827.

11 Hope J. A treatise on the diseases of the heart and great vessels, comprising a new view of the physiology of the heart's action and sounds. London: William Kidd, 1832.

12 Latham PM. Lectures on subjects connected with clinical medicine, comprising diseases of the heart. London: Longman, Brown, Green and Longmans, 1836.

13 Stokes W. Diseases of the heart and the aorta. Dublin: Hodges and Smith, 1854.

14 Lawrence C. Moderns and ancients: the "new cardiology" in Britain 1880-1930. Med Hist 1985;suppl 5:1-33.

15 Marey E-J. Physiologie médicale de la circulation du sang basée sur l'étude graphique des mouvements du coeur et du pouls artériel, avec applications aux maladies de l'appareil circulatoire. Paris: Adrien Delahaye, 1863.

16 Lorain P. Le pouls. Ses variations et ses formes diverses dans les maladies. Paris: J-B Ballière et fils, 1870.

17 Foster B. The sphygmograph in English medical practice [Letter]. Lancet 1866;i:634.

18 Burdon-Sanderson J, Anstie FE. On the application of physical methods to the exploration of the movements of the heart and pulse in disease. No 1. On the theory of the pulse. Lancet 1866;il:517-9.

19 Hollman A. Coronary vasodilators. Med World 1963; 99:217-22.

20 Brunton L. Collected papers on circulation and respiration. London: Macmillan and Co, 1907.

21 Krikler DM. The foxglove, "The Old Woman from Shropshire" and William Withering. J Am Coll Cardiol 1985;5:3A-9A.

22 Brunton TL. On the use of nitrite of amyl in angina pectoris. Lancet 1867;ii:97-8.

23 Murrell $W$. Nitro-glycerine as a remedy for angina pectoris. Lancet $1879 ; \mathbf{i}: 80-1$.

24 Sharpey-Schafer E. History of the Physiological Society during its first fifty years. London: Cambridge University Press, 1927.

25 Hay J. A lecture on James Mackenzie and his message. Br Med J 1930;i:1033-6.

26 Mackenzie J. The venous and liver pulses, and the arhythmic contraction of the cardiac cavities. J Pathol Bacteriol 1894;2:84-154, 273-345.

27 Dudgeon RE. The sphygmograph: its history and use as an aid to diagnosis in ordinary practice. London: Ballière, Tindall \& Cox, 1882.

28 Mackenzie J. The study of the pulse, arterial, venous and hepatic, and of the movements of the heart. Edinburgh: Pentland J Young, 1902.

29 Mackenzie J. New methods of studying affections of the heart. Br Med J 1905;i:519-22, 587-9, 702-5, 759-62, 813-5.

30 Mair A. Sir James Mackenzie MD 1853-1925 general practitioner. Edinburgh: Churchill Livingstone, 1973:95.

31 McMichael J. Sir James Mackenzie and atrial fibrillation-a new perspective. J $R$ Coll Gen Pract 1981; 31:402-6.

32 Waterston D. Sir James Mackenzie's heart. Br Heart J 1939;1:237-48.

33 Bramwell C. John Hay and the founders of the Cardiac Club. Br Heart J 1965;27:849-55.

34 Parkinson J, Bedford DE. Successive changes in the electrocardiogram after cardiac infarction (coronary thrombosis). Heart 1927-8;14:195-212.

35 Wolff L, Parkinson J, White PD. Bundle-branch block with short $P-R$ interval in healthy young people prone to paroxysmal tachycardia. Am Heart $J$ 1930;5: 685-99.

36 Hollman A. Thomas Lewis-the early years. Br Heart J $1981 ; 46: 233-44$

37 Hollman A. Thomas Lewis: physiologist, cardiologist, and clinical scientist. Clin Cardiol 1985;8:555-9.

38 Snellen HA. Two pioneers of electrocardiography. The correspondence between Einthoven and Lewis from 1908-26. Rotterdam: Donker Academic Publications, 1983.

39 Lewis T. Foreword. Br Heart J 1939;1:1-2.

40 Howell JD. Early perception of the electrocardiogram: from arrhythmias to infarction. Bull Hist Med 1984;58:83-98.

41 Krikler DM. Alfred Goodman Levy-Bulawayo's first doctor. Cent Afr J Med 1969;15:97-9.

42 McMichael J. A transition in cardiology: the Mackenzie Lewis era. The Harveian oration of 1975. London: Royal College of Physicians, 1976.

43 Levy AG, Lewis T. Heart irregularities, resulting from the inhalation of low percentages of chloroform vapour, and their relationship to ventricular fibrillation. Heart 1911-12;III:99-112.

44 Black JW, Stephenson JS. Pharmacology of a new adrenergic beta-receptor blocking compound (Nethalide). Lancet 1962;ii:311-4.

45 Cowan J and others. Some notes on the Cardiac Club. Br Heart J 1939;1:97-102.

46 Howell JD. "Soldier's heart": the redefinition of heart disease and speciality formation in early twentieth-century Great Britain. Med Hist 1985; suppl 5:34-52.

47 Campbell $M$. The British Cardiac Society and the Cardiac Club: 1922-1961. Br Heart J 1962;24: 673-95.

48 Krikler DM. Electrocardiography then and now: where next? Br Heart J 1987;57:113-7.

49 McMichael J, Sharpey-Schafer EP. Cardiac output in man by a direct Fick method: effects of posture, venous pressure change, atropine, and adrenaline. $\mathrm{Br}$ Heart J 1944;6:33-40.

50 Wood P. Diseases of the heart and circulation. London: Eyre and Spottiswoode, 1950. 